\title{
Urbani menedžment v evropskem kontekstu
}

Konceptualizacija urbanega menedžmenta že od svojih začetkov v delih Johna Rexa (1968), Raya Pahla (1970, $1975,1979)$ in Petra Williamsa $(1976,1978)$ ni koherentna, vse bolj pa tudi presega meje ene discipline. Urbani menedžment so poskušali definirati številni avtorji, vendar ni nikoli prišlo do enotne opredelitve. Po mnenju Richarda Strena (1993) urbanega menedžmenta dejansko nikoli niti niso poskušali definirati, in to kljub primerjalnemu in analitičnemu delu na področju te poddiscipline. Tako do danes ni znan odgovor na Williamsovo (1978) vprašanje, ali gre pri urbanem menedžmentu za predmet, proces ali strukturo. V prispevku je predstavljena (re)konceptualizacijo urbanega menedžmenta $\mathrm{v}$ okviru modernizacije mestne uprave oziroma njene naloge, da v mestu ustvari zelo potrebno ravnotežje med družbenim in ekonomskim razvojem. Poleg tega so predstavljeni izsledki raziskave »Urbani menedžment $\mathrm{v}$ mestih v Evropski uniji $(E U) \ll$, ki implicirajo, da mesta v Evropski uniji pogosto delujejo po principih urbanega menedžmenta. Pri preverjanju, ali implementacija predlaganega modela urbanega menedžmenta pozitivno vpliva na nekatere indikatorje (ali indekse) uspešnosti, je mogoče ugotoviti, da večje ko je mesto, več dejavnikov urbanega menedžmenta uporablja; bolj ko je mesto ekonomsko uspešno (lizbonski benchmark), več dejavnikov urbanega menedžmenta uporablja, in da moč mesta (indeks moči) ni povezana $\mathrm{z}$ indeksom urbanega menedžmenta, kar lahko pomeni, da avtonomija mestne oblasti ni pomembna za reformiranje mestne uprave. Na podlagi empirične analize je mogoče da sklepati, da koncept urbanega menedžmenta, kot je predstavljen, obstaja in ima pozitiven vpliv na nekatere vidike delovanja mesta.

Ključne besede: urbani menedžment, upravljanje mest, ekonomska uspešnost, decentralizacija, participacija 


\section{Uvod}

Pojavnost urbanega menedžmenta povezujemo z novo vlogo lokalnih oblasti v neoliberalizmu (Davey idr., 1996). V 80. in 90. letih prejšnjega stoletja se je termin urbani menedžment »zapisal « v leksikone razvojnega diskurza ter nadomestil starejši in konvencionalnejši izraz »urbana lokalna (samo)uprava «(Jenkins, 2000). Razvoj koncepta urbanega menedžmenta pa sega še dlje, v 60. leta prejšnjega stoletja, ko so predstavniki urbane sociologije (Pahl, Castells idr.) začeli razvijati tezo o tako imenovanem urbanem managerializmu. ${ }^{[1]}$ Od tega obdobja naprej pa je koncept postal izrazito multidisciplinaren. Zaradi svoje »neulovljive « narave (glej Stren, 1993) so ga discipline (sociologija, urbanizem, arhitektura, ekonomija, politologija in podobno) razlagale z različnimi definicijami, kar se je izražalo v različnih koncepcijah.

Edmundo Werna (1995) opozarja na globalne družbenopolitične in ekonomske spremembe, ki so vplivale na razvoj urbanega menedžmenta. Različne spremembe, kot so razumevanje ekonomskega pomena mest, kriza države blaginje, vzpon neoliberalističnega pristopa, pojavnost tekmovalnosti mest in transformacija vladanja v vladovanje, ${ }^{[2]}$ so močno vplivale ne samo na razumevanje, ampak tudi na vsebino urbanega menedžmenta. Sprva se je glede na posebnost urbanega okolja, ki je po svoji naravi lokalno, glede na kompleksnost in soodvisnost procesov pa ima prvine podjetniškega okolja, na urbane problematike poskušalo odgovoriti s principi tržnega menedžmenta. ${ }^{[3]}$ Pozneje se je koncept upravljanja mest na podlagi načel menedžmenta začel razvijati v smeri specifičnega menedžmenta. Na podlagi uporabe tega orodja v praksi so v 80. letih v znanosti začeli uporabljati termin »urbani menedžment «.

Definicijo urbanega menedžmenta je vsekakor treba iskati v okvirih specifik mesta, ki s svojimi značilnostmi določa tip vladanja in vodenja ter vladovanja in menedžiranja. ${ }^{[4]} \mathrm{Da}$ je pomembno analizirati in razviti specifična orodja upravljanja mest, podpirata dva argumenta. Prvi je hitra globalna urbanizacija, ${ }^{[5]}$ zaradi katere je mesto dom že vsakemu drugemu človeku. Drugi, s prvim povezani argument pa je, da zaradi ekonomske pomembnosti mest za nacionalne skupnosti ni večjih trendov deurbanizacije - mesta so torej realnost, njihove težave je nujno treba začeti reševati. Med te »težave « prištevamo vse večje potrebe po urbanih dobrinah in infrastrukturi, tako $s$ strani prebivalcev kot vlagateljev: prebivalci zahtevajo okolje, ki ponuja visoko kakovost bivanja in zaposlitvene priložnosti, vlagatelji pa zahtevajo visoko specializirano delovno silo ter zanesljivo in kakovostno urbano infrastrukturo (Van Dijk, 2006). Večina urbane problematike namreč ne izhaja iz kompleksnega, zahtevnega in gosto naseljenega okolja, temveč je posledica nereševanja te problematike $\mathrm{z}$ ustreznim orodjem (Cheema, 1993; Werna, 1995; Bramezza, 1996;
Prud'homme, 1996; Van Dijk, 2006). Pravzaprav bi lahko rekli, da se morajo mesta, če želijo uspešno reševati urbane probleme, nanje najprej ustrezno odzvati. Za to je treba najprej razumeti okolje, v katerem (in s katerim) delujejo urbani vodje in menedžerji. Meine Pieter Van Dijk (2006) meni, da je to svet, v katerem se aktivnosti in izzivi urbanih menedžerjev nenehno spreminjajo. David Harvey (1989) opisuje to kot premik iz menedžiranja v podjetništvo (ang. entrepreneurialism). Obstaja torej realno povpraševanje po specializiranih upravljavskih orodjih, ki bi pomagala (političnim in upravnim) vodjem pri dolgoročnemu reševanju (ali vsaj poskušanju reševanja) kompleksnih in večplastnih problemov. Kljub neizpodbitni realni potrebi po konceptualizaciji takih orodij, ki bi se lahko manifestirala $\mathrm{v}$ konceptu urbanega menedžmenta, pa do danes še vedno ni jasno, kaj natančno je urbani menedžment in kdo ga izvaja. Stren (1996: 415) v tem kontekstu doda: »/.../ [I]zziv raziskovalcem je, da odgovorijo na pojavljajoče se probleme v urbani realnosti ter $s$ svojimi dognanji seznanijo širšo javnost, javnopolitične akterje in aktiviste $\mathrm{v}$ lokalnih skupnostih, hkrati pa vzdržujejo kredibilno raven logičnega argumenta in znanstvene integritete. Ta dva cilja nista nezdružljiva.«

Cilj članka je predstaviti rekonceptualizacijo urbanega menedžmenta, saj ima - kot pravi Michael Mattingly (1994) ta bolj malo možnosti, da preživi v hitro spreminjajočem se okolju idej in konceptov, brez podpore globalne raziskovalne skupnosti. V tem kontekstu se v članku Mattinglyju odgovori $\mathrm{v}$ treh točkah. Prvič, poudarjeno je pomanjkanje konsenza pri definiranju urbanega menedžmenta, nato so predstavljene obstoječe definicije oziroma njihov presek. Drugič, predstavljeni so nova vizija urbanega menedžmenta in njegove vsebine, $\mathrm{v}$ osrednjem delu pa je preverjeno, kako se tehnike in orodja urbanega menedžmenta uporabljajo v mestih v Evropski uniji (v nadaljevanju: EU). To je predstavljeno prek empirične raziskave, narejene na vzorcu 58 mest v EU. Pridobljeni podatki so dodatno primerjani z nekaterimi kazalci (predvsem ekonomske) uspešnosti mest in tako dokazujejo, ali ima urbani menedžment dokazljiv vpliv na nekatere vidike delovanja mesta.

\section{Definicija urbanega menedžmenta}

Urbani menedžment se pogosto opisuje kot neulovljiv koncept (Stren, 1993; Mattingly, 1994) prav zaradi splošnega izogibanja akademske in strokovne javnosti, da bi dosegli nekakšen konsenz. O vzrokih za nastali položaj ni večjih ugibanj, saj nekateri avtorji celo odkrito kritizirajo vlogo Svetovne banke in projekta naslovom Urban management programme, ki naj bi imel izrazito zaviralni moment do enotnega definiranja. Pa vendar je, da bi urbani menedžment zaživel, treba tistim, ki ga bodo uporabljali, jasno predstaviti njegov pomen in vsebino. Nov pristop nastaja s poudarjanjem novih obveznosti in dolžnosti z vidika menedžerskega procesa in z identificiranjem 
tistih urbanih subjektov, s katerimi je treba tako ravnati (Mattingly, 1994). Izvor urbanega menedžmenta lahko iščemo pri Pahlu (1975), ki se v knjigi, naslovljeni Whose city?, sprašuje, kdo razdeljuje oziroma ima na voljo redke urbane dobrine. Osredotoči se na vlogo čuvajev (ang. gatekeepers), ki naj bi imeli najpomembnejšo vlogo pri alokaciji teh redkih urbanih dobrin (misli predvsem na zemljišča). V tem kontekstu Williams (1978) nasprotuje nadaljnji poglobitvi teze. Pozneje nekateri avtorji vseeno poskušajo z definicijo. Kalpana Sharma (1989) urbani menedžment dojema kot $\gg / . . . /$ niz dejavnosti, ki skupaj oblikujejo in vodijo družbeni, teritorialni in ekonomski razvoj mest. Glavne naloge urbanega menedžmenta so poseganje na ta področja, da bi dosegli boljši ekonomski razvoj in zagotavljali urbane storitve in dobrine «. Carole Rakodi (1991: 542) meni, da »/.../ je cilj in smisel urbanega menedžmenta zagotoviti, da so vse komponente $\mathrm{v}$ sistemu usklajene in delujejo tako, da mesto vsakodnevno funkcionira. To osnovno funkcioniranje bo omogočilo in spodbudilo razne gospodarske dejavnosti in ekonomske tokove, občanom pa tudi zagotovilo dostop do urbane infrastrukture in storitev«. Forbes Davidson in Peter Nientied (1991: 85) urbani menedžment prav tako definirata skozi prizmo njegove vloge in menita, da je $\gg / . . . /$ bistvo urbanega menedžmenta prevzemanje dejavne vloge pri razvoju, upravljanju in koordiniranju resursov, za doseganje mestnih razvojnih ciljev «. Tudi Bikas Chakrabarty (1998: 505) ga definira podobno: »/.../ z uporabo koncepta urbanega menedžmenta je mogoče doseči zadane cilje in rešiti urbane probleme $\mathrm{z}$ učinkovito izrabo fizičnih, finančnih, človeških in drugih virov, ki so na voljo urbanemu sektorju $\ll$.

Mattingly (1994: 201-205) dodaja urbanemu menedžmentu strateško sestavino; meni, da je »/.../ urbani menedžment sprejemanje trajne odgovornosti za proces doseganja ciljev za določene subjekte. /.../ [T] a odgovornost pomeni, da se določi, kaj je treba storiti, potem pa je to dejansko treba izvesti in se nato prepričati, ali je bilo to izvedeno, da bi se mesto razvijalo«. Za Mattinglyja je urbani menedžment tudi »/.../ javna uprava ali razvojni menedžment oziroma organizacijski menedžment «. Giles Clarke (1991) razume urbani menedžment kot orodje oziroma način, s katerim spodbujamo učinkovitost in uspešnost pri uporabljanju tehničnih, človeških in finančnih virov, tako v javnem kot zasebnem sektorju. $V$ tej definiciji se kaže tudi njegovo razumevanje mest kot generatorjev nacionalnih prihodkov, saj meni, da je naloga urbanega menedžmenta doseči trajnostni razvoj mesta, kar po Clarku pomeni doseganje ekonomske moči. Shabbir Cheema (1993: 7) je v definicijo urbanega menedžmenta vpeljal razmerja med nevladnimi organizacijami in lokalno oblastjo: »/.../[D]elovanje urbanega menedžmenta je omogočanje vladnim in nevladnim organizacijam, da lažje prepoznajo problem, oblikujejo javno politiko ali program in izvedejo implementacijo z optimalni- mi rezultati. Izziv urbanega menedžmenta je, da se učinkovito odzove na probleme posameznega mesta in optimizira njegovo delovanje «. Podobno je že leta 1985 razmišljal Anthony Churchill (1985: V), ki je menil, da »/.../ termin urbani menedžment ne opisuje le sistema nadzora v mestu, temveč je bogatejši in zajema tudi mnoge interakcije, ki jih imajo prebivalci med seboj in tudi z mestno oblastjo «.

Kenneth Davey (1993: 4) meni, da se »/.../ urbani menedžment ukvarja z javnimi politikami, načrti in s programi, $s$ katerimi poskuša zagotoviti, da ima prebivalstvo v mestu dostop do osnovne infrastrukture, bivanjske infrastrukture in zaposlitve. Čeprav je ta dostop močno, če ne celo še bolj, odvisen tudi od zasebnih iniciativ in podjetij, ima lokalna vlada najpomembnejšo besedo pri strateškem pristopu in izvajanju regulativne funkcije v mestu «. Van Dijk (2006: 56) pozneje ponudi to široko definicijo: »/.../[U]rbani menedžment je prizadevno usklajevanje dejanj javnih in zasebnih akterjev za reševanje problemov - $s$ katerimi se srečujejo občani mesta - , da bi posledično oblikovali konkurenčno mesto, ki je usmerjeno $\mathrm{v}$ trajnostni razvoj in vse prebivalce obravnava enakovredno. « Podobno široko definicijo zastavi Ilaria Bramezza (1996: 34), ki navaja, da je »/.../ urbani menedžment koordiniran razvoj in realizacija celostnih strategij s pomočjo vključevanja in participacije vseh pomembnih urbanih akterjev, katerih namen je prepoznati, oblikovati in izkoristiti potenciale trajnostnega razvoja mesta «. Doseganje konsenza o tem, kaj je urbani menedžment in kako ga definirati, je za nadaljnji razvoj koncepta zelo pomembno. Mattingly (1994) celo meni, da bi jasna definicija urbanega menedžmenta za koncept pomenila preboj na agende političnih akterjev in s tem tudi udejanjanje koncepta $v$ praksi (praktična konvergenca). Prav tako pa bi občani oziroma uporabniki lahko prepoznali kakovost koncepta in zahtevali njegovo implementacijo.

\section{Urbani menedžment kot upravno orodje}

\subsection{Urbani menedžment in politologija}

Do zdaj smo uspeli predstaviti le pomanjkanje konvergence na področju definiranja urbanega menedžmenta, ob tem pa nismo ponudili alternative - torej svoje percepcije, kaj je urbani menedžment, in tudi, kaj ni urbani menedžment (kar je v okviru razprave prav tako pomembno, če ne celo pomembneje). Hkrati je nujno, da se zavedamo študijskega okvira (če nekoliko provokativno povzamemo Williamsovo (1987) retorično vprašanje), znotraj katerega poskušamo urbani menedžment razumeti. Proučevanje urbanega menedžmenta je zaznamovano $s$ (kvazi)interdisciplinarnostjo, čeprav prave interdisciplinarne študije ali pristopa po mnenju Strena (1993) ni mogoče najti. 
[6] Menimo, da bi bilo v nadaljnjih poskusih (re)definiranja urbanega menedžmenta mogoče preseči dominacijo nekaterih disciplin (urbanizem, urbana sociologija, arhitektura) na tem področju ter odpreti vrata tudi nekoliko bolj »oddaljenim « disciplinam, predvsem upravni znanosti in politologiji. Slednji proučevanje mest ni tuje. Že Robert Dahl (1967) na primeru mest zgradi svojo (pozneje zelo priljubljeno) temo o lokalni pluralistični demokraciji, kako je mogoče večje probleme rešiti le $s$ tako imenovanimi pragmatičnimi koalicijami (povezovanje prek ideoloških ločnic). Zaradi Dahlovega pristopa je $\mathrm{k}$ urbanim študijam pritegnilo tudi politologe, čeprav so v disciplini takrat prevladovali sociologi in geografi. »Vendar se je politologija (ne pa tudi javna uprava) v tem obdobju osredotočila le na manjša mesta ter (morda namenoma) zanemarjala velike, kompleksnejše in konfuzne metropole.« (Stren, 1996: 404.)

Prvi pravi politološki pristop $\mathrm{k}$ urbanim študijam je teorija urbanega režima (Stone, 1989; Stoker, 1996; Hamel, 1999), ki je nastala v 80. in 90. letih v ZDA. V nasprotju z zagovorniki elitističnih teorij, ki se sprašujejo, kdo vlada, se predstavniki teorije urbanega režima sprašujejo, kako zagotoviti ustrezne zmogljivosti za reševanje urbanih problematik in razvoj lokalne skupnosti. Clarence Stone (1989) poudarja, da zaradi izredno kompleksnega urbanega okolja nobena politična skupina ne more prevzeti nadzora, zato se ustvarjajo tako imenovani režimi, sestavljeni iz različnih akterjev (predvsem delničarjev), ki imajo zmožnost realizacije javne politike. Moč tako dobi tisti, ki ima zmožnosti in sposobnosti rešiti določen problem. Z analizo transformacije lokalnih oblasti in lokalnega upravljanja so zagovorniki teorije urbanega režima poskušali dokazati, da je učinkovitost upravljanja mesta odvisna predvsem od zmožnosti oblasti, da v proces oblikovanja javnih politik vključi več zasebnih (ekonomskih) akterjev. Tako se ustvarjajo posamezni režimi, katerih cilj je reševanje natančno določenega problema. Največja slabost teorije urbanega režima je prav njena naklonjenost ustvarjanju parcialnih omrežij, ki lahko celo zmanjšujejo demokratičnost in participativnost $v$ mestu. Dopušča namreč velik vpliv in moč posameznih ekonomskih in političnih skupin, ki zaradi nizke stopnje legitimnosti navadno ne nosijo objektivne odgovornosti za posledice svojih odločitev.

$\mathrm{Na}$ tej točki se teorija urbanega režima precej približa Pahlovim (1979) čuvajem, ki bdijo nad alokacijo redkih urbanih dobrin. Pahl odkriva zametke razmerja moči in urbane elite (pozneje »čuvaji «) v 14. stoletju, ko se je kljub liberalizaciji urbanega okolja koncentracija elite ohranjala ali celo stopnjevala. Ravno ob spremljanju razvoja te elite ugotavlja, da ima politična elita $\mathrm{v}$ kapitalistični postindustrijski družbi veliko večjo vlogo, kot ji jo urbani sociologi pripisujejo. $S$ stališča nadaljnjega razvoja koncepta urbanega menedžmenta je vključevanje Pahlovega razumevanja vpliva urbanih menedžerjev na proces alokacije urbanih dobrin ključno.

\subsection{Urbani menedžment kot menedžment}

Iz termina urbani »menedžment « je jasno, da govorimo o menedžmentu $^{[7]}$ (podobno ugotovi že Chakrabarty (1998)). Gre torej za poseben tip menedžmenta, ki je značilen za mestne uprave, ki jih zaznamujeta dve lastnosti. Prvič, delujejo v zelo dinamičnem okolju, ki ga Helga Leitner in Eric Sheppard (1998) imenujeta celo podjetniško. Drugič, še vedno so del ustroja javnega sektorja ali bolje javne uprave, zato so zavezane načelu javnega dobrega in omejene s številnimi (nacionalnimi) zakoni, ki preprečujejo hitro, odzivno in konkurenčno delovanje mestne uprave ter $s$ tem tudi mesta. Urbani menedžment je torej skupek orodij in dimenzij, ki v okviru pristojnosti mestnih uprav poskušajo zagotoviti optimalno delovanje teh, širše pa tudi drugih mestnih organov in javno-političnih področij (na primer analize stroškov in koristi (ang. cost-benefit analyses), ocene vpliva (ang. risk impact assessments), evalvacijo letnih načrtov, pripravljanje letnih načrtov, benchmarking in podobno).

Urbani menedžment lahko razumemo tudi kot tehtnico, ki lovi ravnotežje med potrebami delničarjev (ekonomski subjekti, vlagatelji, multinacionalke) in déležnikov (prebivalci, civilna družba, nevladne organizacije). Gre torej za ravnotežje med družbenim in ekonomskim razvojem, ki pa mora biti nujno v sozvočju, saj deluje kot pozitivna povratna zanka. Če v mesto privabimo vlagatelje, morajo ti imeti na voljo delovno silo in ustrezno infrastrukturo. Delovno silo pa privabimo predvsem $s$ koncentracijo delovnih mest in kakovostnim bivanjem. Če želimo obdržati (ali celo privabiti) vlagatelje, moramo privabiti tudi delovno silo in obratno. Ta centrifugalna sila mesta tako deluje sama po sebi (Stren, 1993), naloga urbanega menedžmenta pa je, da mestna uprava deluje po takih načelih, da je zmožna ohranjati ravnotežje med obema silama. Nekateri se morda s takim razumevanjem ne bi strinjali, saj se to ravnotežje uravnava (tudi) z javnimi politikami, ki jih sprejema mestna politika. Vendar menimo, da je tukaj najpomembnejše razumevanje med urbanim menedžmentom (ang. urban management) in menedžiranjem mesta (ang. managing the city), kar je temeljni prispevek politološke znanosti k razvoju koncepta urbanega menedžmenta. Če se je, kot navaja Stren (2000), zaradi uvajanja podjetniških načel v javno upravo v 60 . in 70 . letih urbana uprava (ang. urban administration) v 80. letih preprosto preimenovala v urbani menedžment, potem je urbani menedžment reformirana mestna uprava. Širše razumevanje urbanega menedžmenta kot urejanja in vodenja vsega, kar je v mestu, pa je pravzaprav menedžiranje mesta. $\mathrm{V}$ ta proces so vključeni tudi drugi (politični in ekonomski) akterji.

Vsekakor urbanega menedžmenta ne gre enačiti z upravljanjem mesta. Urbani menedžment je manj kot to, saj v primeru upravljanja mesta govorimo o urbanem vladovanju, v primeru 
urbanega menedžmenta pa o operacionalni ravni delovanja. Urbani menedžment je torej »le« reformiran način delovanja mestne uprave (in ne tudi mestne vlade). Razmejevanje menedžmenta (ang. management) in vladovanja (ang. governance) je v splošni literaturi že tako označeno za težavno (glej Dayton, 2001; Oehler-Şincai, 2008). V literaturi prevladujeta dva pristopa $\mathrm{k}$ razumevanju urbanega menedžmenta. Prvi ga razume v najširšem smislu, torej kot delovanje vseh akterjev v mestu (in širše) za optimizacijo delovanja mesta. Je vsako dejanje, katerega cilj sta razvoj in upravljanje mesta, urbani menedžment? Širše razumevanje urbanega menedžmenta torej zajema tudi odločevalsko funkcijo. $\mathrm{V}$ tem primeru se pojma vladovanje in menedžment precej zbližata. Menimo, da tako razumevanje in gledanje na urbani menedžment ni ustrezno, saj zajeda $\mathrm{v}$ procese in strukture urbanega vladanja in vladovanja, ki ima specifično funkcijo sprejemanja odločitev (politik, programov, usmeritev, načrtov), ne zajema pa implementacije teh odločitev. Nirmala Rao (2007: 4) v tem kontekstu posebej poudari $» / . . . /$ cities are governed and managed $\ll{ }^{[8]}$ Precej ilustrativna pa je tudi razlaga Alberta Reissa (1970): »Če je urbano vladovanje odnos med vladajočimi in vladanimi, je urbani menedžment odnos med servers and the served in service delivery. « ${ }^{[9]}$

\subsection{Model urbanega menedžmenta}

Najzahtevnejši del rekonceptualizacije urbanega menedžmenta je pravzaprav določanje vsebine koncepta. Če je na podlagi literature jasno, kakšna je naloga urbanega menedžmenta (optimalno delovanje mesta in/ali mestne uprave), potem je naslednji korak določiti, s katerimi orodji naj bi se ta naloga dosegla. $S$ pomočjo pregleda odzivov mestnih uprav na zunajsistemske vplive smo ugotovili, da se nekatere rešitve ponavljajo, izomorfno obnašanje mest pa širi to uporabo $\mathrm{v}$ splošno rabo. $\mathrm{V}$ tem kontekstu tudi razumemo rekonceptualizacijo koncepta in ilustrativno lahko prikažemo urbani menedžment kot tehtnico, ki lovi ravnotežje med potrebami delničarjev (ekonomski subjekti, vlagatelji, multinacionalke) in déležnikov (prebivalci, civilna družba, nevladne organizacije). Gre torej za ravnotežje med družbenim in ekonomskim razvojem, ki pa mora biti nujno v sozvočju, saj deluje kot pozitivna povratna zanka. Če v mesto privabimo vlagatelje, morajo ti imeti na voljo delovno silo in ustrezno infrastrukturo. Delovno silo pa privabimo predvsem $s$ koncentracijo delovnih mest in kakovostnim bivanjem. Če želimo obdržati (ali celo privabiti) vlagatelje, moramo privabiti tudi delovno silo in obratno. Ta centrifugalna sila mesta tako deluje sama po sebi (Stren, 1993), naloga urbanega menedžmenta pa je, da mestna uprava deluje po takih principih, da je zmožna ohranjati ravnotežje med obema silama.

Izhajali smo iz domneve, da je urbani menedžment način delovanja mesta (oziroma kot smo ugotovili pozneje, mestne uprave), ki je usmerjen k izboljšanju ekonomskih in družbenih razmer bivanja v mestih (Mumtaz in Wegelin 2001). Vsebina urbanega menedžmenta se mora torej vezati na optimizacijo delovanja mesta oziroma spodbujanja te. Obstaja širok nabor dobrih praks, v katerih je navedeno, kako se spopasti s pestrimi in številnimi urbani problemi (Program Združenih narodov za naselja, ang. United Nations Human Settlements Programme, 2004) in kako doseči optimalen razvoj mesta. Bramezza (1996) meni, da je odziv mest sicer lahko različen glede na predispozicije (zgodovinske, zakonodajne, makroekonomske) in okolje (politično, ekonomsko, upravo), vendar obstaja način upravljanja, ki omogoča optimalno izrabo potenciala predispozicij in okolja. Naše izhodišče temelji prav na tem temeljnem razumevanju. Urbani menedžment naj vsebuje vse tiste dimenzije, ki zajemajo osnovne koncepte optimalnega upravljanja mesta. V tem smislu je najbolj smotrna izdelava dimenzij, ki pokrivajo glavne sklope dokazano ugodnega delovanja mestnih uprav na uspešnost (ekonomsko in/ali družbeno) mest. Dimenzije tako pokrivajo vsa tista področja, ki so v literaturi predstavljena kot temeljna za optimizacijo. Tako smo se oprli predvsem na idejne koncepte Bramezze (1996), Jamesa Svare (2003), Robina Hambletona (2004) in Van Dijka (2006), ki iščejo optimizacijo $v$ »decentralizaciji « (Van Dijk), »participaciji (Hambleton), »avtonomni vlogi menedžerjev « (Svara) in »konkurenčnosti mesta « ter »trajnostnem razvoju « (Bramezza). »Obstaja možnost, da se konceptu urbanega menedžmenta pridruži tudi kakšna druga (doslej v literaturi zanemarjena) dimenzija, zato menimo, da je koncept vedno rastoč in fluiden, saj se okolje delovanja mestnih uprav zelo hitro spreminja, prav tako pa tudi izzivi, ki jih to okolje zastavlja.« (Van Dijk, 2006: 4.) V prvi fazi pa je treba preveriti, ali te osnovne dimenzije dejansko vplivajo na uspešnost (ekonomsko in/ali družbeno) mesta.

\section{Raziskava »Urbani menedžment $v$ mestih EU« 4.1 Metodologija}

Manifestacija predlaganega modela urbanega menedžmenta (za podroben opis modela glej Bačlija, 2010) se kaže v stopnji uporabe predlaganih orodij urbanega menedžmenta $\mathrm{v}$ praksi. Da ne bi ostali le pri teoretiziranju, je treba predlagani model preizkusiti v družbeno-politični realnosti. Prvič, ali model sploh obstaja, in drugič, ali ima realne učinke na nekatere vidike delovanja mest. $\mathrm{V}$ ta namen si zastavimo tri hipoteze.

- Večje ko je mesto, več dejavnikov urbanega menedžmenta uporablja.

- Ekonomsko uspešnejše ko je mesto, ${ }^{[10]}$ več dejavnikov urbanega menedžmenta uporablja.

- Močnejše ko je mesto, ${ }^{[11]}$ več dejavnikov urbanega menedžmenta uporablja. 
Podatke o pojavnosti dimenzij urbanega menedžmenta v praksi smo pridobili pri urbanih menedžerjih - torej iz neposrednega vira v mestni upravi. Ker je eden od konstitutivnih dejavnikov urbanega menedžmenta » vloga menedžerja «, ki vključuje tudi indikatorje, ki so vezani na subjektivno (ali bolje neformalno) percepcijo, je bilo najbolj smiselno, da smo za ciljno skupino izbrali urbane menedžerje. $V$ tem kontekstu moramo razložiti dve zadevi. Prvič, kdo so urbani menedžerji, in drugič, kako smo izbrali vzorec opazovanih mest. Določevanje, kdo je urbani menedžer (sploh glede na pestrost ureditev v EU), je precej oteženo (Borja, 1996; Hughes, 2003; Van Dijk, 2006), zato smo izhajali iz treh domnev. Prvič, ker je urbani menedžment po vsebini in funkciji menedžment, je njegovo izvajanje naloga menedžerjev; drugič, ker je Svara (2003) na primeru mest v ZDA že natančno raziskal in določil vlogo urbanih menedžerjev, menimo, da lahko izhajamo iz njegove definicije (urbani menedžer kot najvišji nevoljeni vodja mestne uprave), in tretjič, ker so pretekle raziskave v Evropi (Hambleton in Sweeting, 1999; Daemen in Schaap, 2000) pokazale, da obstaja povezava med vlogo menedžerja in uspešnostjo mesta, lahko predvidevamo, da ta sloj v upravi obstaja. Ciljna skupina so torej visoki javni uslužbenci v mestnih upravah. Drugo pojasnilo je povezano z izbiro opazovanih mest. $V$ prvi fazi raziskovalnega postopka smo se odločili za evropska mesta, predvsem zaradi relativne bližine opazovanih enot. Nato pa smo določili skupino mest, za katera so bili dostopni podatki, na podlagi katerih smo določili njihovo uspešnost (neodvisne spremenljivke). V tem smislu smo bili precej omejeni, saj je zbiranje primerlji- vih podatkov bolj ali manj vezano na projekt Urban Audit ${ }^{[12]}$. Ker projekt Urban Audit večinoma zbira podatke za države članice EU, smo svojo populacijo (evropska mesta) zožili na »mesta v EU «, znotraj tega pa na skupino 120 mest, ki so vključena v natančno zbiranje podatkov za 250 indikatorjev, ki so bili že omenjeni. Izbor 120 evropskih mest, ki pomenijo reprezentativni vzorec, je bil opravljen po tem merilu (Urban Audit, 2004: v raziskavo je vključeno vsaj $15 \%$ celotne evropske populacije; v raziskavo so vključene vse prestolnice; kjer je bilo mogoče, so vključena tudi glavna mesta regij; v raziskavo so vključena velika (več kot 250.000 prebivalcev) in srednje velika (najmanj 50.000 in največ 250.000 prebivalcev) mesta; izbrana mesta so geografsko enakomerno porazdeljena v vsaki državi članici. V zadnji fazi raziskave smo pridobljene podatke obdelali z računalniškim programom SPSS, pri čemer smo v isti matrici združili odgovore in spremenljivke iz baze podatkov projekta Urban Audit.

\subsection{Rezultati}

Pri predstavitvi pridobljenih rezultatov moramo biti nekoliko previdni, saj združevanje podatkov iz pridobljenih vprašalnikov in obstoječih baz podatkov pomeni kar nekaj ovir. Poleg tega obstaja nevarnost nenamerne generalizacije, ki je lahko posledica (ne)vzročnosti nekaterih spremenljivk, nepravilnih odgovorov vprašanih (zaradi jezikovnih omejitev je bil vprašalnik preveden $\mathrm{v}$ šest jezikov - nekatere strokovne izraze pa

Preglednica 1: Korelacije med spremenljivkami (Pearsonov koeficient in beta koeficient)

\begin{tabular}{|c|c|c|c|c|c|c|}
\hline & Participacija & Decentralizacija & $\begin{array}{l}\text { Avtonomija } \\
\text { urbanega } \\
\text { menedžerja }\end{array}$ & $\begin{array}{l}\text { Konkurenčnost } \\
\text { mesta }\end{array}$ & Trajnostni razvoj & $\begin{array}{l}\text { Indeks } \\
\text { urbanega } \\
\text { menedžmenta }\end{array}$ \\
\hline \multirow{4}{*}{$\begin{array}{l}\text { število prebi- } \\
\text { valcev }\end{array}$} & $P=-0,204$ & $P=0,268^{*}$ & $P=0,033$ & $P=0,155$ & $P=0,343^{*}$ & $P=0,212$ \\
\hline & $($ sig. $=0,136)$ & (sig. $=0,048)$ & $($ sig. $=0,809)$ & $($ sig. $=0,263)$ & (sig. $=0,011)$ & $($ sig. $=0,124)$ \\
\hline & $\beta=-0,230$ & $\beta=0,239$ & $\beta=0,035$ & $\beta=-0,089$ & $\beta=0,343$ & $\beta=0,120$ \\
\hline & (sig. $=0,376)$ & (sig. $=0,300)$ & (sig. $=0,876)$ & (sig. $=0,731)$ & $($ sig. $=0,182)$ & (sig. $=0,661)$ \\
\hline \multirow{4}{*}{$\begin{array}{l}\text { povprečni BDP } \\
\text { per capita }\end{array}$} & $P=-0,270^{*}$ & $P=0,110$ & $P=-0,255$ & $P=0,153$ & $P=0,254$ & $P=-0,004$ \\
\hline & (sig. $=0,069)$ & $($ sig. $=0,460)$ & (sig. $=0,081)$ & (sig. $=0,315)$ & (sig. $=0,092)$ & $($ sig. $=0,981)$ \\
\hline & $\beta=-0,043$ & $\beta=0,068$ & $\beta=-0,463$ & $\beta=0,322$ & $\beta=0,276$ & $\beta=0,035$ \\
\hline & (sig. $=0,869)$ & $($ sig. $=0,767)$ & (sig. $=0,055)$ & (sig. $=0,223)$ & $($ sig. $=0,285)$ & (sig. $=0,900)$ \\
\hline \multirow{4}{*}{$\begin{array}{l}\text { indeks moči } \\
\text { mesta }\end{array}$} & $P=-0,102$ & $P=0,240$ & $P=-0,210$ & $P=0,018$ & $P=-0,001$ & $P=0,002$ \\
\hline & $($ sig. $=0,501)$ & $($ sig. $=0,104)$ & $($ sig. $=0,153)$ & $($ sig. $=0,908)$ & $($ sig. $=0,997)$ & (sig. $=0,991)$ \\
\hline & $\beta=-0,010$ & $\beta=0,354$ & $\beta=-0,087$ & $\beta=0,058$ & $\beta=-0,060$ & $\beta=0,106$ \\
\hline & $($ sig. $=0,964)$ & $($ sig. $=0,104)$ & $($ sig. $=0,690)$ & $($ sig. $=0,799)$ & $($ sig. $=0,790)$ & $($ sig. $=0,666)$ \\
\hline \multirow{4}{*}{$\begin{array}{l}\text { lizbonski } \\
\text { benchmark }\end{array}$} & $P=0,267^{*}$ & $P=0,031$ & $P=-0,002$ & $P=0,091$ & $P=0,141$ & $P=0,199$ \\
\hline & (sig. $=0,091)$ & (sig. $=0,844)$ & $($ sig. $=0,988)$ & $($ sig. $=0,577)$ & (sig. $=0,386)$ & $($ sig. $=0,219)$ \\
\hline & $\beta=0,317$ & $\beta=-0,108$ & $\beta=-0,175$ & $\beta=0,185$ & $\beta=0,269$ & $\beta=0,225$ \\
\hline & $($ sig. $=0,159)$ & (sig. $=0,612)$ & $($ sig. $=0,414)$ & (sig. $=0,402)$ & (sig. $=0,220)$ & $($ sig. $=0,342)$ \\
\hline
\end{tabular}

Opombe: * Tveganje je manjše od $10 \% ; \mathrm{N}=58$.

Vir: Bačlija (2010) 
je nemogoče dosledno prevesti) in drugih ovir (glej Heberlein in Baumgartner, 1978; Armstrong in Lusk, 1987; Singer idr., 1992). Opozoriti je treba tudi na relativno nizke vrednosti povezav med spremenljivkami, vendar je zaradi majhnega vzor$\mathrm{ca}^{[13]}$ tovrstna težava pričakovana.

V preglednici 1 je predstavljena ekstrakcija opravljenih korelacij - Pearsonov koeficient, beta koeficient s pripadajočimi tveganji za dimenzije urbanega menedžmenta, indeks urbanega menedžmenta in nekatere neodvisne spremenljivke (število prebivalcev, gostota naseljenosti, povprečen BDP per capita ${ }^{[14]}$, povprečna stopnja zaposlenosti, indeks moči mesta ${ }^{[15]}$, lizbonski benchmark ${ }^{[16]}$ in druge spremenljivke, ki v tem članku niso predstavljene).

Najprej lahko opazimo, da se nakazuje, da so mesta z višjo vrednostjo indeksa moči mesta $\mathrm{v}$ večji meri decentralizirana. To lahko pripišemo večji avtonomiji mesta, kar pomeni več pristojnosti za odločanje o lastni interni decentralizaciji. Nakazana je tudi korelacija med mestno decentralizacijo in BDP per capita. Poleg tega smo v raziskavi ugotovili, da je več kot polovica $(53,6 \%)$ mest decentralizirana, vendar je ta podatek vprašljiv, saj ima le 18,9 \% mest izvoljene sublokalne predstavnike, katerih odločitve so zavezujoče za mestno oblast.

Pri analiziranju dimenzije participacija uporabnikov smo opazovali ločeno oba tipa participacije: politično participacijo in participacijo potrošnikov. Ker smo ugotovili, da obstaja zelo visoka verjetnost, da mesto vključuje meščane kot uporabnike in hkrati tudi kot državljane (v $75 \%$ ), ločeno indeksiranje (še posebej pri majhnih vzorcih) ne bi prineslo statistično značilnih razlik. Po pričakovanjih je nakazana pozitivna povezava med lizbonskim benchmarkom in participacijo. Pri bivariatni analizi (Pearsonov koeficient $=0,267$; standardna napaka napovedi $=0,091)$ se povezava nakazuje, pri linearni regresiji pa se povezava še okrepi $(\beta=0,317)$, kar pomeni, da moramo največ vpliva pripisati lizbonskemu benchmarku. Torej podobno, kot že ugotavlja Poul Erik Mouritzen (1989) - večja ko je vključenost občanov v procese odločanja, večja je konkurenčnost mesta. Zavedati se moramo, da je lizbonski benchmark najvišji v skandinavskih mestih, $\mathrm{v}$ katerih obstaja dolgoletna tradicija močnih in demokratičnih lokalnih skupnosti (Lane, 1994). Višja participacija bi tako lahko bila tudi posledica institucionalnega okvira in demokratične tradicije kot »le« urbanega menedžmenta. Nadalje smo zasledili nakazano negativno povezavo med številom prebivalcev in participacijo. To niti ne preseneča, saj že Mouritzenov model (1989) predvideva alienacijo prebivalcev v velikih entitetah. Nekoliko bolj pa preseneti nakazana negativna povezava s povprečnim BDP $\mathrm{v}$ mestu. Pri nadaljnji analizi z linearno regresijo pa se vpliv te spremenljivke popolnoma izgubi.
Tretja dimenzija avtonomnost urbanega menedžerja prikazuje popolnoma drugačno sliko $\mathrm{v}$ mestih $\mathrm{v}$ EU kot $\mathrm{v}$ mestih $\mathrm{v}$ ZDA (Mouritzen in Svara, 2002; Svara, 2003). Glede na opazovani vzorec smo v raziskavi ugotovili, da je večina urbanih menedžerjev imenovana (86\%), nekaj pa tudi voljenih (14\%). Nevezanost na mandat političnih funkcionarjev je sicer zaželena (Borja, 1996), vendar težko uresničljiva, zato se razume, da so vsi bolj ali manj vezani na politični mandat župana in mestnega sveta. Morda je še pomembneje, v kakšni vlogi urbani menedžer vidi samega sebe. Tradicionalna ureditev v lokalni samoupravi navaja, da je urbani menedžer le izvajalec političnih odločitev in tako vidi svojo vlogo $68,4 \%$ vprašanih. Zanimivo pa je, da jih kar tretjina (33\%) meni, da imajo vlogo uradnega odločevalca. $S$ po $22,8 \%$ sledita vlogi neuradni odločevalec in mediator oziroma posredovalec (med različnimi interesnimi skupinami, prebivalci in podobno). Pri pregledu povezav z neodvisnimi spremenljivkami naletimo na precej črno sliko. Medtem ko imajo avtonomni urbani menedžerji v ZDA dokazan (Svara, 2003) pozitiven učinek na nekatere ekonomske kazalnike uspešnosti mest, nimajo urbani menedžerji v EU nikakršnega podobnega pozitivnega učinka.

Zadnji dimenziji - konkurenčnost mesta in trajnostni razvoj sta v okviru naše raziskave mišljeni kot kakovost mestnih uprav (menedžmenta). Torej smo merili le tiste aktivnosti, ki so $\mathrm{v}$ pristojnosti slednje ( $\mathrm{v}$ članku že navedene). Izračuni kažejo nakazano negativno korelacijo med gostoto prebivalstva in trajnostnim razvojem ter med trajnostnim razvojem in povprečno stopnjo zaposlenosti. To lahko nakazuje, da imajo zelo gosto naseljena mesta druge prioritete in niso orientirana na trajnostni razvoj. Ko seštejemo in rekodiramo pridobljene vrednosti ter združimo vse dimenzije $\mathrm{v}$ tako imenovani indeks urbanega menedžmenta (Bačlija, 2010), lahko opazimo nekatere kumulativne učinke. Nakazuje se pozitivna povezava med indeksom urbanega menedžmenta in številom prebivalcev (Pearsonov koeficient $=0,212)$, kar lahko nakazuje, da so večja mesta bolj nagnjena $\mathrm{k}$ reformiranju mestnih uprav po načelih urbanega menedžmenta. ${ }^{[17]}$ Druge spremenljivke se statistično značilno ne povezujejo z indeksom. Pri linearni regresiji pa ugotovimo nakazano povezavo med indeksom urbanega menedžmenta in lizbonskim benchmarkom, kar pomeni, da sta konkurenčnost mesta in urbani menedžment lahko povezana.

\section{Sklep}

Mesta postajajo zaradi vse večjega števila nalog in pristojnosti, ki so prenesene z nacionalne ravni, tista teritorialna enota, ki vse samostojneje odloča o svojem ekonomskem razvoju in konkurenčnih prednostih, zaradi česar so mesta nosilci ekonomskega razvoja in hkrati oblikovalci strategije, s katero je mogoče privabiti in obdržati vlagatelje in visoko specializirano delovno silo (Hall, 1993). Kot protiutež ekonomski učinkovitosti in 
strateški prilagodljivosti se pojavlja tako imenovana urbana problematika. To lahko kategoriziramo: (1) kot problematiko neenakomerne polarizacije in fragmentacije (družbe, dobrin), (2) kot visoko stopnjo onesnaženosti, (3) kot razkrajajočo se infrastrukturo in (4) kot visoko stopnjo družbene detoriacije (kriminal in nasilje) (Businaro, 1994; nacionalni raziskovalni svet, ang. National Research Council, 1999). Vsi ti problemi so tesno povezani z velikim številom in gostoto prebivalstva v mestih. Različne raziskave kažejo, da je optimalna velikost lokalne entitete, ki še omogoča učinkovito zagotavljanje javnih storitev, med 25.000 in 70.000 prebivalci (Dahl, 1967; Hirsch, 1968; Mouritzen, 1989; Richardson, 1993). Večina mest večkrat preseže to število, kar pomeni, da so prebivalci mest prikrajšani za nekatere osnovne storitve. Douglas Yates (1977) meni, da so urbani problemi skoraj nerešljivi zaradi prevelike heterogenosti mesta, kar onemogoča koherentno načrtovanje in oblikovanje javnih politik, in prevelike centralizacije, ki onemogoča fleksibilno mestno upravo. Cheema (1993: 3) meni, da sta na urbano problematiko mogoča le dva odgovora, in sicer $\gg / . . . /$ zmanjšati pritisk priseljevanja ali izboljšati urbani menedžment «.

Predlagamo (re)konceptualizacijo urbanega menedžmenta kot reforme delovanja mestnih uprav, njegova naloga pa je ustvarjati ravnotežje med družbenim in ekonomskim razvojem, ki mora biti nujno v sozvočju, saj deluje kot pozitivna povratna zanka. Če v mesto privabimo vlagatelje, morajo ti imeti na voljo delovno silo in ustrezno infrastrukturo. Delovno silo pa privabimo predvsem s koncentracijo delovnih mest in kakovostnim bivanjem. Če želimo obdržati (ali celo privabiti) vlagatelje, moramo privabiti tudi delovno silo in obratno. To ravnotežje lahko ohranimo (ali vzpostavimo) s pomočjo petih glavnih mehanizmov (dimenzij koncepta): $\mathrm{z}$ decentralizacijo mesta, $s$ participacijo, $z$ vlogo menedžerja, $s$ konkurenčnostjo mesta in trajnostnim razvojem. Vedeti moramo, da je to samo poskus rekonceptualizacije in da je dopolnjevanje modela vedno mogoče ( $v$ stilu novega javnega menedžmenta, ki zajema množico mehanizmov, ki se $\mathrm{v}$ realnosti pojavljajo $\mathrm{v}$ različnih kombinacijah).

$\mathrm{Na}$ podlagi empirične raziskave (model smo testirali na reprezentativnem vzorcu 58 mest v EU) lahko sklepamo, da je predlagani koncept urbanega menedžmenta $\mathrm{v}$ mestih EU v precej splošni uporabi. Pri preverjanju, ali implementacija predlaganega modela urbanega menedžmenta pozitivno vpliva na nekatere indikatorje (ali indekse) uspešnosti, smo ugotovili, da večje ko je mesto, več dejavnikov urbanega menedžmenta uporablja; ekonomsko uspešnejše ko je mesto (lizbonski benchmark), več dejavnikov urbanega menedžmenta uporablja, in da moč mesta (indeks moči) ni povezana z indeksom urbanega menedžmenta, kar lahko pomeni, da avtonomija mestne oblasti ni pomembna za reformiranje mestne uprave. Na podlagi empirične analize lahko trdimo, da koncept urbanega menedžmenta, kot smo si ga zamislili, obstaja in ima pozitiven vpliv na nekatere vidike delovanja mesta.

\section{Irena Bačlija}

Univerza v Ljubljani, Fakulteta za družbene vede, Oddelek za politologijo, Katedra za analizo politik in javno upravo, Ljubljana, Slovenija E-pošta: irena.baclija@fdv.uni-lj.si

\section{Opombe}

${ }^{[1]}$ »Urban managerialism«, ki ga bomo poimenovali kar urbani managerializem, je teorija o urbanih procesih, katere utemeljitelj je Ray E. Pahl, ki je izhajal iz sociološke teorije Webra. Urbani managerializem je na osrednje mesto urbane sociologije postavil razmerja moči in medsebojnih konfliktov ter vlogo trga in javnih institucij, določil pa je tudi, da na razporeditev prebivalstva v mestu najbolj vpliva redistribucija in alokacija urbanih dobrin. Pahl (1975) je kot urbane dobrine razumel predvsem stanovanjsko infrastrukturo (ang. housing) in izobrazbo. Ker sta obe urbani dobrini omejeni, »urbani menedžerji« ali »čuvaji» (ang. gatekeeperji) omejujejo dostop do njih. Termin urbani managerializem se pozneje v literaturi spremeni v urbani menedžment (glej Mattingly,1994; Werna, 1995; Chakrabarty, 1998; McGill, 1998) in počasi spremeni pomen, ko prehaja iz urbane sociologije v ekonomijo (z neoliberalizmom in ekonomsko vlogo mest za nacionalni BDP) in pozneje v politologijo in upravno znanost (vladovanje).

${ }^{[2]}$ Termin vladovanje v članku uporabljamo kot prevod za termin governance (glej Splichal, 2008).

${ }^{[3]}$ Menedžment se je začel razvijati in napredovati kot način dela predvsem v 70. letih 20. stoletja. Gospodarska kriza je spodbudila podjetnike $v$ zasebnem sektorju, da so začeli razmišljati o spremembah v delovni organizaciji. Prav tako je na spremembe v delovni organizaciji vplival razvoj tehnologij (informacijskih, telekomunikacijskih), kar je po mnenju Normana Flynna in Franza Strehla (1996) še posebej vplivalo na upravne sisteme.

${ }^{[4]} V$ sodobni upravni znanosti se odpira diskurz o temeljnih pojmih in njihovem medsebojnem odnosu, predvsem kot posledica (kvazi) sodobnih konceptov in teorij. Upravljanje se namreč vse bolj zamenjuje ali dopolnjuje z menedžmentom, čeprav njun odnos ni popolnoma jasen in dorečen, poleg tega se $v$ upravo in upravljanje vriva koncept vladovanja (ang. governance), s tem pa tudi vladanja in vodenja ter posledično nedorečenosti njihovih definicij znotraj upravnega področja. Deloma omenjene nejasnosti izhajajo iz »uvoza« terminoloških izrazov iz tuje literature (predvsem anglosaške) in nedoslednosti pri njihovi uporabi v domači literaturi. Po drugi strani pa nekatere nedorečenosti povzroča pomanjkanje ustreznih prevodov v slovenščino. Tako na primer nimamo primernih izrazov za ločevanje upravljanja od »menedžiranja« in vladovanja. Pogosto (ali skoraj kot pravilo) se termin upravljanje uporablja kot nadpomenka za vse prej naštete dejavnosti (Brezovšek in Bačlija, 2010).

[5] Pričakuje se, da se bo število urbane populacije s 3,3 milijarde v letu 2007 povečalo na 6,4 milijarde v 2050 (Združeni narodi, 2008).

${ }^{[6]}$ To pa ne pomeni, da ne bi bila potrebna ali da ni pomembna. Marjan Brezovšek in Damir Črnčec (2007) po podobni analogiji govorita o interdisciplinarnem pristopu k upravni znanosti. Menita, 
da tak pristop nima samo hevristične vrednosti, ampak tudi posebno preskriptivno vrednost.

${ }^{[7]}$ Termina upravljanje in menedžment se v slovenščini v nekaterih primerih pojavljata kot sinonima. Tako se upravljanje nanaša na delovanje lastnikov, menedžment pa na načrtovanje, organiziranje, vodenje in kontroliranje dela ter vseh nalog in aktivnosti, ki jih opravljajo zaposleni (Kustec-Lipicer, 2007). Če lastnik sam dela s svojo lastnino, odloča o njej s svojim delom. Če pa pusti drugim delati na svoji lastnini, potem odloča o njej tako, da odloča o delu drugih s tem, da ga uravnava. »Temu odločanju lastnika, ki je družbeno-ekonomsko opredeljeno, pravimo upravljanje. Upravljanje je torej odločanje o lastnini.« (Rozman, 1996: 7-8.) Menedžerji pa načrtujejo, organizirajo, vodijo in kontrolirajo. Pri tem so vsi procesi delno že začeti v upravljanju. Zato je upravljanje nekaj drugega kot menedžment, vodenje pa je le del menedžmenta. Vendar pa podobnega razčlenjevanja v javnem sektorju ne poznamo. Pogosto menedžment razumemo le kot reformirano, napredno različico administriranja ali celo upravljanja. Hendri Kroukamp in Liezel Lues (2008) menita, da so menedžerske funkcije lokalnega javnega sektorja pravzaprav le podaljšanje oziroma razširitev javne administracije za zagotavljanje javnih storitev $v$ lokalni skupnosti moderne demokratične družbe.

${ }^{[8]}$ Za boljšo ponazoritev smo izjavo pustili v izvirniku.

${ }^{[9]}$ Za boljšo ponazoritev smo del izjave pustili v izvirniku.

${ }^{[10]}$ Ekonomsko uspešnost merimo z indeksom lizbonski benchmarking (ločeno pa bomo merili tudi povezavo z nekaterimi indikatorji ekonomske uspešnosti, kot so BDP per capita, in s stopnjo zaposlenosti (Urban Audit, 2004).

[11] Glede na indeks moči (Urban Audit, 2004).

${ }^{[12] ~ G l e j ~ s p l e t n o ~ s t r a n ~ p r o j e k t a ~ U r b a n ~ A u d i t, ~ k i ~ j e ~ d o s t o p n a ~ n a: ~}$ http://www.urbanaudit.org.

[13] Pri tem je treba opozoriti, da je kljub »majhnosti« vzorca to največja tovrstna raziskava, ki je bila do zdaj opravljena med urbanimi menedžerji v EU.

${ }^{[14]}$ BDP je vsota vseh končnih dobrin in storitev, proizvedenih v mestu $v$ določenem obdobju ( $v$ našem primeru eno leto). Za izračun BDP na prebivalca pa celotni BDP delimo s celotno populacijo (ne glede na starost ali delovno aktivnost). Težavo pri dejanskem izračunu pomeni dnevna migracija delavcev, ki se ne štejejo za prebivalce, čeprav proizvajajo končne dobrine in storitve $v$ mestu. Da bi se izognili vplivu nacionalnih ekonomij, smo opazovali BDP mesta glede na BDP celotne države. Tako smo ugotovili relativno (in ne absolutno) vrednost BDP glede na državno povprečje. Sledili smo formulaciji, da nacionalno BDP-povprečje pomeni vrednost 100 , vrednost BDP v mestu pa je ocenjena glede na delež, ki presega povprečje nacionalnega BDP ( $v$ \%) ali pa je pod njim.

${ }^{[15]}$ Kako močno lahko mestne oblasti posameznega mesta oblikujejo oziroma vplivajo na uspešnost mesta, je najbolj odvisno od moči mestne oblasti. V okviru tega so pri projektu Urban Audit (glej Urban Audit, 2004) pripravili tako imenovani »indeks moči«, ki je sestavljen iz večjih indikatorjev, kot so: avtonomnost mestnih oblasti pri izdatkih; avtonomnost mestnih oblasti pri obdavčevanju in delež nacionalnega BDP, namenjen lokalni samoupravi. Indeks poskuša ponazoriti, kako močno vlogo ima mestna oblast znotraj posameznega nacionalnega sistema.

${ }^{[16]}$ Lizbonski benchmark je indeks za ocenjevanje realizacije Lizbon- ske strategije in je tesno povezan s konkurenčnostjo opazovane entitete ( $v$ našem primeru mesta). Sestavljen je iz teh spremenljivk: - BDP glede na celotno populacijo mesta;

- delovna produktivnost (BDP na zaposleno osebo);

- zaposleni prebivalci (delež zaposlenih med 15 in 64 letom starosti);

- stopnja zaposlenosti starejših delavcev (delež zaposlenih med 55 in 64 letom starosti);

- dolgoročna nezaposlenost starejše populacije (delež tistih, ki so nezaposleni več kot eno leto ter so stari med 55 in 64 let);

- delež prebivalcev, ki se izobražuje višjem in visokem šolstvu (delež prebivalcev med 15 in 24 letom starosti, ki se izobražuje $v$ višjem in visokem šolstvu glede na celotno populacijo);

- nezaposlenost mladih (delež mladih med 15 in 24 letom starosti, ki so nezaposleni vsaj šest mesecev).

${ }^{[17]}$ Frannie Leautier (2006) pride do podobnih sklepov pri proučevanju velikosti mesta in nekaterih javnih storitev v mestu.

\section{Zahvala}

Avtorica prispevka se zahvaljuje uredniku in anonimnemu recenzentu za pripombe, ki so pripomogle k izboljšavi besedila.

\section{Viri in literatura}

Armstrong, J. S., in Lusk, E. J. (1987): Return postage in mail surveys: A meta-analysis. Public Opinion Quarterly, 51(3), str. 233-248. DOI: 10.1086/269031

Bačlija, I. (2010): Urbani menedžment: koncept, dimenzije in orodja. Ljubljana, Univerza v Ljubljani, Fakulteta za družbene vede.

Borja, J. (1996): Cities: New roles and forms of governing. V: Cohen, M. A., Blair, R. A., Tulchin, J. S., in Garland, A. M. (ur.): Preparing for the urban future: Global pressures and local forces, str. 70-89. Washington, The Woodrow Wilson Center Press.

Tulchin, J. S., in Garland, A. M. (ur.): Preparing for the urban future: Global pressures and local forces, str. 70-89. Washington, The Woodrow Wilson Center Press.

Bramezza, I. (1996): The competitiveness of the European city and the role of urban management in improving the city's performance. Hag, CIP-Data Koninklijke Bibliotheek.

Brezovšek, M., in Bačlija, I. (2010): Sodobna upravna misel. Ljubljana, Univerza v Ljubljani, Fakulteta za družbene vede.

Brezovšek, M., in Črnčec, D. (2007): Demokratična uprava in tajnost podatkov. Ljubljana, Univerza v Ljubljani, Fakulteta za družbene vede.

Businaro, U. L. (1994): Technology and the future of the cities. Responding to the urban malaise: An agenda for the European Union. Bruselj, Komisija Evropskih skupnosti.

Chakrabarty, B. K. (1998): Urban management and optimizing urban development models. Habitat, 22(4), str. 503-522. DOI: 10.1016/S01973975(98)00029-0

Cheema, S. G. (1993): The challenge of urban management: Some issues. V: Cheema, S. G., in Ward, S. E. (ur.): Urban management policies and innovations in developing countries, str. 1-17. London, Praeger Westport.

Churchill, A. (1985): Foreword. V: Lea, J. P., in Courtney, J. M. (ur.): Cities in conflict: Studies in the planning and management of Asian cities, str. V. 
Washington, Svetovna banka.

Clarke, G. (1991): Urban management in developing countries: A critical role. Cities, 8(2), str. 93-107. DOI: 10.1016/0264-2751(91)90003-A

Daemen, H., in Schaap, L. (2000): Citizen and city: Developments in fifteen local democracies in Europe. Rotterdam, Erasmus University.

Dahl, R. A. (1967): The city in the future of democracy. The American Political Science Review, 61(4), str. 953-970. DOI: 10.2307/1953398

Davey, K. (1993): Elements of urban management. Washington, Svetovna banka.

Davey, K., Batley, R., Devas, N., Norris, M., in Pasteur, D. (1996): Urban management: The challenge of growth. Aldershot, Avebury.

Davidson, F., in Nientied, P. (1991): Introduction. Cities, 8(2), str. 82-86. DOI: 10.1016/0264-2751(91)90001-8

Dayton, K. N. (2001): Governance is governance. London, Independent Sector.

Dillinger, W. (1994): Decentralization and its implications for service delivery. Washington, DC, Svetovna banka.

Flynn, N., in Strehl, F. (ur.) (1996): Public sector management in Europe. Upper Saddle River, NJ, Prentice Hall.

Hall, P. (1993): Forces shaping urban Europe. Urban studies, 30(6), str. 883-898. DOI: 10.1080/00420989320080831

Hambleton, R. (2004): Beyond new public management - city leadership, democratic renewal and the politics of place. Prispevek je bil predstavljen na konferenci, z naslovom City Futures International Conference, ki je potekala od 8. do 10. julija v Čikagu v ZDA. Tipkopis.

Hambleton, R., in Sweeting, D. (1999): Restructuring our decision making (three models for local governance). Planning, 1344(12), str. 474-488.

Hamel, G. (1999): Bringing Silicon Valley inside. Harvard Business Review, 71(5), str. 70-87.

Harvey, D. (1989): The Urban Experience. Oxford, Blackwell.

Heberlein, T. A., in Baumgartner, R. (1978): Factors affecting response rates to mailed surveys: A quantitative analysis of the published literature. American Sociological Review, 43(4), str. 447-462. DOI: $10.2307 / 2094771$

Hirsch, S. C. (1968): Cities are people. New York, Viking Press.

Hughes, O. E. (2003): Public management and administration: An introduction. Hampshire, Palgrave.

Jenkins, P. (2000): Urban management, urban poverty and urban governance: Planning and land management in Maputo. Environment and Urbanization, 12(1), str. 137-152. DOI: 10.1177/095624780001200110

Kroukamp, H., in Lues, L. (2008): Improving local management. V: de Vries, M. S., Reddy, P. S., in Haque, M. S. (ur.): Improving local government: Outcomes of comparative research, str. 77-92. Hampshire, Palgrave McMillan.

Kustec-Lipicer, S. (2007): Vrednotenje izbranih modelov merjenja kakovosti v slovenski javni upravi. V: Haček, M., in Zajc, D. (ur.): Slovenija v evropski družbi znanja in razvoja, str. 197-214. Ljubljana, Fakulteta za družbene vede.

Lane, J. (1994): Will public management drive out public administration? Asian Journal of Public Administration, 16(2), str. 139-151.

Leautier, F. (2006): Cities in a globalizing world: Governance, performance and sustainability. Herndon, VA, Svetovna banka.

Leitner, H., in Sheppard, E. (1998): Economic uncertainty, interurban competition and the efficacy of entrepreneurialism. V: Hall, T., in Hub- bard, P. (ur.): The enterpeneurial city, str. 285-308. Chichester, Wiley.

Mattingly, M. (1994): Meaning of urban management. Cities, 11(3), str. 201-205. DOI: 10.1016/0264-2751(94)90060-4

McGill, R. (1998): Urban management in developing countries. Cities, 15(6), str. 463-471. DOI: 10.1016/S0264-2751(98)00041-9

Mouritzen, P. E. (1989): City size and citizens' satisfaction: Two competing theories revisited. European Journal of Political Research, 17(6), str. 661-688. DOI: 10.1111/j.1475-6765.1989.tb00212.x

Mouritzen, P. E., in Svara, J. H. (2002): Leadership at the apex: Politicians and administrators in western local governments. Pittsburgh, University of Pittsburgh Press.

Mumtaz, B., in Wegelin, E. (2001): Guiding cities. Washington, DC, Svetovna banka.

Nacionalni raziskovalni svet (1999): Governance and opportunity in metropolitan America. Washington, DC, National Academy Press.

Oehler-Şincai, I. M. (2008): Strengths and weaknesses of the new public management (NPM) - cross-sectional and longitudinal analysis. Prispevek je bil predstavljen na konferenci z naslovom New Public Management and the Quality of Government, ki je potekala od 13. do 15. novembra v Göteborgu na Švedskem. Tipkopis.

Pahl, R. E. (1970): Patterns of urban life. Boston, Longman.

Pahl, R. E. (1975): Whose city?: And further essays on urban society. Baltimore, Penguin Books.

Pahl, R. E. (1979): Managerialism, managers and self-management. Area, 11(3), str. 88-90.

Program Združenih narodov za naselja (2004): The state of the world's cities. Nairobi.

Prud'homme, R. (1996): The dangers of decentralization. The World Bank Research Observer, 10(2), str. 201-220. DOI: 10.1093/wbro/10.2.201

Rakodi, C. (ur.) (1991): The urban challenge in Africa. Tokio, United Nations University Press.

Rao, N. (2007): Cities in transition: Growth, change and governance in six metropolitan areas. London, Routledge. DOI: 10.4324/9780203391150

Reiss, A. (1970): The services and the served in service. Urban Affairs Annual Review, 4(3), str. 561-576.

Rex, J. (1968): The sociology of a zone transition. V: Pahl, R. E. (ur.): Readings in urban sociology, str. 212-283. Oxford, Pergamon.

Richardson, H. (1993): Problems of metropolitan management in Asia. V: Cheema, S. G. (ur.): Urban management: Policies and innovations in developing countries, str. 51-75. Westport, CT, Greenwood Praeger Press.

Rozman, R. (1996): Kako prevesti »management« v slovenščino: management, menedžment, upravljanje, poslovodenje, vodenje, ravnanje? Organizacija, 29(1), str. 5-18.

Sharma, K. S. (1989): Municipal management. Urban Affairs Quarterly India, 21(4), str. 47-53.

Singer, E., Hippler, H., in Schwartz, N. (1992): Confidentiality assurances in surveys: Reassurance or threat? International Journal of Public Opinion Research, 4(3), str. 256-268. DOI: 10.1093/ijpor/4.3.256

Splichal, S. (2008): Deregulacija, denacionalizacija, depolitizacija. Delo, 5, 6. 12. 2008 , str. 5 .

Stoker, G. (1996): Redefining local democracy. V: Pratchett, L., in Wilson, D. (ur.): Local democracy and local government, str. 188-209. Basingstoke, Macmillan.

Stone, C. N. (1989): Regime politics. Lawrence, University Press of Kansas. 
Stren, R. E. (1993): Urban management in development assistance: An elusive concept. Cities, 10(2), str. 125-139. DOI: 10.1016/02642751(93)90044-J

Stren, R. E. (1996): Administration of urban services. V: Gilbert, R. Stevenson, D., Girardet, H., in Stren, R. (ur.): Making cities work: The role of local authorities in the urban environment, str. 62-112. London, Earthscan Publications.

Stren, R. E. (2000): New approaches to urban governance in Latin America. Prispevek je bil predstavljen na seminarju, z naslovom IDRC and Management of Sustainable Urban Development in Latin America: Lessons learnt and Demands for Knowledge, ki je potekal 6. in 7. aprila v Montevideu v Urugvaju. Tipkopis

Svara, J. H. (2003): Effective mayoral leadership in council-manager cities: Reassessing the facilitative model. National Civic Review, 92(2), str. 157-172. DOI: 10.1002/ncr.14

Urban Audit (2004): Methodological handbook: 2004 Edition. Bruselj. Van Dijk, M. P. (2006): Managing cities in developing countries: The theory and practice of urban management. Cheltenham, Edward Elgar Publishing.

Werna, E. (1995): The management of urban development, or the development of urban management? Problems and premises of an elusive concept. Cities, 12(5), str. 353-359. DOI: 10.1016/0264-2751(95)00069-X

Williams, P. (1976): The role of the institutions in the inner London housing market: The case of Islington. Transactions of the Institute of British Geographers, 1(1), str. 72-82. DOI: 10.2307/621314

Williams, P. (1978): Urban managerialism: A concept of relevance? Area, 10(3), str. 236-240.

Yates, D. (1977): The ungovernable city: The politics of urban problems and policy making. Cambridge, MA, MIT Press.

Združeni narodi (2008): Demographic yearbook 2006. New York. 